\title{
Radiation sterilisation and tissue banking
}

\author{
Peter Myint
}

Published online: 22 June 2018

(C) Springer Nature B.V. 2018

This Special Edition is dedicated to Professor Gly O Phillips for his contribution towards tissue banking from the aspect of radiation sterilisation. Radiation sterilisation is an integral part of tissue banking, especially in musculoskeletal tissue banking. Professor Phillips is an imminent radiation chemist who has published over 700 research items in journals and books in various subjects, mainly in food science and tissue banking. His vision and strategy of using radiation as a means to sterilise tissues has made a great contribution to the expansion of tissue banking worldwide, particularly in developing countries, and his achievements remain relevant to this day since his involvement started in the 1970s.

Radiation is the only terminal sterilisation method with unique properties-(1) it can sterilise products or items in final packaging, (2) it does not require a postirradiation sterility test and (3) cost effectiveness; for these reasons irradiation is widely used in sterilisation of medical and pharmaceutical products. As a radiation chemist, Professor Phillips instantly recognised the benefits that radiation technology could bring to tissue banking and how this could benefit the developing countries where imported surgical implants are expensive and beyond the reach of many patients. Together with the International Atomic Energy

P. Myint $(\square)$

Wrexham, UK

e-mail: peter.myint@vtbank.org
Agency (IAEA), the organisation which promotes the peaceful use of nuclear energy, regional programmes were set out to support setting up of tissue banks around the world.

Over the span of a half a century, the course of tissue sterilisation by irradiation has evolved as much as tissue banking has developed. For a long time, the sterilisation dose for tissues was adopted at $25 \mathrm{kGy}$ (known as $2.5 \mathrm{Mrad}$ ) as in pharmaceutical products. This dose is derived from Bacillus Pumilus, a bacteria which is the most resistant organism to radiation, however, this organism is never found in tissues. Unlike medical products, tissues are sensitive to radiation due to their biological nature, and some tissue establishments, mainly in the USA, in the late 90s and early 2000s started to opt for aseptic processing without sterilisation, or using much lower radiation dose for decontamination purpose prior to processing. Unfortunately, this led to some incidents of transmission of bacteria and fungi from tissues to recipients. This led to the return of radiation sterilisation, albeit a new approach in relation to the dose applied.

A meeting was held in 2004 in Wrexham, United Kingdom, gathering experts from tissue banking as well as from the radiation industry to address the role of radiation sterilisation for tissues. Tissue bankers started to adopt what was happening in the pharmaceutical industry where dose setting based on "bioburden" was increasingly adopted rather than the 
standard $25 \mathrm{kGy}$ dose. ISO11137 dose setting methods were studied for tissue sterilisation however the challenge was that, unlike medical products, tissues are scarce in number and not practical to sacrifice large numbers in destructive testing to determine the bioburden. It was also recognised that a combination of strict donor selection, aseptic processing, GMP standards and stringent quality assurance meant that the bioburden of tissues was expected to be low, making it possible to use the lower sterilisation dose. Over the next decade, a new dose setting method such as $\mathrm{VD}_{\max 15}$ requiring fewer number of samples for testing was developed which offered a way to use a lower dose whilst giving the same level of sterility assurance. Nowadays, a low sterilisation dose of $15 \mathrm{kGy}$ or lower is widely used in many tissue establishments.

Tissue banking has come a long way from an unregulated cottage industry in the 70 s to now a truly regulated global business. This would not have happened without the aid of irradiation sterilisation which supported the expansion across the globe. Professor Phillips turned 90 in 2017 and we, in the tissue banking community, celebrate his birthday with the publication of this Special Issue. In this Special issue, we see contributions from Asia Pacific and Latin America regions, the IAEA programmes, the application of radiation knowledge extended to tissue banking, and the fundamentals of free radical chemistry and many others, all in attribution to the work of Professor Phillips. As for me, it is my honour and privilege to be associated with this publication and I like to thank those who kindly contributed to this Special Issue.

Dr. Peter Myint

Guest Editor 